the IV All-Ukrainian Scientific and Practical Conference of Young Scientists and Students (May 5, 2017, Chernihiv). Chernihiv National Pedagogical University named after T.G. Shevchenko. (Ed.). I. Zhara. Chernighiv, pp. 93-96. [in Ukrainian].

8. Zakhozhyj, V. V. (2011). Metodyka formuvannja ghotovnosti starshoklasnykiv do samostijnykh zanjatj fizychnymy vpravamy [Methodology of formation of high school students' readiness for independent exercises by physical exercises]. Extended abstract of candidate's thesis. Lucjk, p. 20. [in Ukrainian].

9. Zvaryshhuk, O. M. (2002). Vykhovannja vidpovidaljnosti starshoklasnykiv za svij fizychnyj stan [Upbringing the responsibility of senior pupils for their physical condition]. Candidate's thesis. Lviv, p. 198. [in Ukrainian].

10. Kleshchev, Yu. N. (2005). Voleybol. Shkola trenera [Volleyball. School Coach]. Moscov, p. 79. [in Russian].

11. Kovalev, V. D., Golomazov, V. A. \&
Keraminas, S. A. (2001). Sportivnye igry [Sport games]. Moscov, p. 318. [in Russian].

12. Nosko, M. O., Ljapyn, V. P., Seroshtan, V. M., Maslov, V. M. \& Ghryshko, L. Gh. (2009). Pidvyshhennja rivnja rukhovoji aktyvnosti jak chynnyk zmicnennja zdorov'ja uchniv ta studentsjkoji molodi [Increase in motor activity as a factor in health promotion of students]. Bulletin of Chernigov State Pedagogical University named after T.G. Shevchenko. Issue 69. Series: Pedagogical sciences. Physical education and sports. Chernighiv, pp. 144-149. [in Ukrainian].

13. Redjko, T. M. (2016). Osoblyvosti vykorystannja kenghu dzhampinghu v osvitnjomu procesi uchniv starshykh klasiv. [Features of using kengu jumping in the educational process of high school students]. Scientific journal of the National Pedagogical University named after M.P. Drahomanov. Series 15: Scientific and pedagogical problems of physical culture (physical culture and sports). 2016. Vol. 3(2), pp. 291-295. [in Ukrainian].

Стаття надійшла до редакції 11.07.2019

УДК 793.31.077

DOI:

Магдалина Марушка, здобувач кафедри загальної педагогіки та дошкільної освіти Дрогобищького державного педагогічного університету імені Івана Франка

\title{
СТАНОВЛЕННЯ УКРАЇНСЫКИХ ХОРЕОГРАФІЧНИХ ШКІЛ У КОНТЕКСТІ РОЗВИТКУ ЄВРОПЕЙСЬКОЇ ХУДОЖНЬОЇ КУЛЬТУРИ ПОЧАТКУ ХХ СТ.
}

Стаття присвячена аналізу історії формування хореографічних шкіл та студій в Украӥні на початку ХХ століття. Становлення украӥнської професійної хореографічної освіти в Украйні тісно пов'язано з розвитком класики, з формуванням західноєвропейської, а саме, французької і італійськоӥ шкіл та перших таниңювальних студій у XIX cm. У перші десятиліття XX ст. були започатковано систему навчальних хореографічних закладів. Базовим принцииом навчання у хореографічних иколах стала традиція класичного танцю, яка має продовження і сьогодні.

Ключові слова: хореографічна освіта; хореографічна школа; класична хореографія; народно-сценічна хореографія; хореографічне мистецтво.

תim. 5.

Mahdalyna Marushka, Postgraduate Student of the General and Preschool Education Department Drohobych Ivan Franco State Pedagogical University

\section{THE FORMATION OF UKRAINIAN CHOREOGRAPHIC SCHOOLS IN THE CONTEXT OFTHE DEVELOPMENT OF THE EUROPEAN ARTISTIC CULTURE OF THE EARLY TWENTIETH CENTURY}

The article is devoted to the analysis of the history of the formation of choreographic schools and studios in Ukraine at the beginning of the 20th century. The formation of Ukrainian professional choreographic education in Ukraine is closely linked to the development of classics, with the formation of Western European, namely, the French and Italian schools and the first dance studios in the nineteenth century. In the first decades of the twentieth century. the system of educational choreographic establishments was started. The basic principle of studying in choreographic schools is the tradition of classical dance, which continues today.

In conditions of economic decline, military and political struggle, there was a marked rise in cultural and scientific life, which was caused by the aspirations of the Ukrainian national revival. Only in 1918 the State Drama School was founded, the Ukrainian State Theater, solemnly opened by the Ukrainian Academy of Sciences. Ukrainian schools and gymnasia began to appear in different regions. 


\section{СТАНОВЛЕННЯ УКРАЇНСЬКИХ ХОРЕОГРАФІЧНИХ ШКІЛ У КОНТЕКСТІ РОЗВИТКУ СВРОПЕЙСЬКОЇ ХУДОЖНЬОЇ КУЛЬТУРИПОЧАТКУ ХХ СТ.}

In order to harmoniously combine in the structural forms of the national ballet and in the vocabulary of classical and folk dance, choreographers attempted to theatricalize folk patterns, making them more complicated by the virtuoso elements of classics. These searches were effective: for the first time in the history of the ballet theater classical and Ukrainian folk-stage choreography united, becoming a fruitful ground for creating a kind of domestic dance school.

In general, the development of Ukrainian choreography in the early twentieth century took place in the context of social and historical and political developments in Ukraine. In this period there was a spiritual uplift, the embodiment of cultural searches, the emergence of powerful talents. A specific feature of this period of development of Ukrainian culture was its ideological and humanistic content, which relied on universal human ideals reproduced in the national genre forms.

For the establishment of Ukrainian professional choreographic education in Ukraine from the first studios and schools in the nineteenth century. Of great importance was the mastery of the laws of the classics and the values of the Western European, in particular the French and Italian choreographic schools. It was at the beginning of the twentieth century. the foundations were laid and the system of educational choreographic institutions formed on the traditions of classical dance, which continues to exist and develop today.

Keywords: choreographic school; choreographic education; folk-stage choreography; choreographic art.

П остановка проблеми. Вивчення засад становлення хореографічної освіти, зокрема, хореографічних шкіл та студій в Україні на початку ХХ століття $\epsilon$ доволі значимим для сучасних досліджень, адже їх виокремлення виявляє характерні риси еволюції сценічно-хореографічного мистецтва, окреслює розвиток традицій української народної і класичної сценічної хореографії, відроджує творчі здобутки видатних майстрів минулого.

Однак, розвиток українського сценічнохореографічного мистецтва окресленого періоду у сучасних наукових працях не висвітлено, зокрема, генеза розвитку хореографічних шкіл та спеціальної професійної хореографічної освіти на тлі піднесення європейської хореографічної культури.

Актуальність дослідження визначається потребою обгрунтування особливостей формування українських хореографічних шкіл та студій початку XX ст. у зв'язку з європейськими культуротворчими процесами того часу.

Мета статті - окреслити засади впливу європейської художньої культури на процес становлення хореографічних шкіл в Україні на початку XX ст.

Аналіз останніх досліджень і публікацій. Становлення та розвиток хореографічної освіти, формування мистецьких шкіл, авторських студій, тощо в Україні досліджена дуже фрагментарно. Лише зараз з'являються праці, в першу чергу, театрознавців, балетознавців та хореографів, опосередковано пов'язані із розвитком хореографічної освіти в Україні. Це, зокрема, розвідки таких українських дослідників як М. Загайкевич, Ю. Станішевський та ін. Незаповненою прогалиною залишаються дослідження у царині історії педагогіки щодо засад хореографічної освіти початку XX ст.

Особливо цінним доробком $є$ монографії
Ю. Станішевського. У відомому дослідженні “Балетний театр України. 225 років історії національного професійного хореографічного мистецтва. 1778 - 2003 р.” об'єктом детального наукового мистецтвознавчого аналізу $\epsilon$ формування сценічної хореографічної культури України, проблеми синтезування класичного та народного танців.

Проблемно-теоретичному аналізу хореогафії присвячені роботи М. Загайкевич та В.Пасютинської. У праці М. Загайкевич "Драматургія балету" розглядаються жанрові особливості балетної музики, взаємозв'язок музичних і хореографічних виражальних засобів.

Монографія М. Загайкевич "Українська балетна музика" присвячена дослідженню фольклорних джерел української балетної музики. Автор деталізовано аналізує час розквіту української класичної театральної драматургії [5]. Ретельному викладу жанрової приналежності українських балетних творів 1917 - 1975 рр., особливостям їх драматургічної побудови присвячене дисертаційне дослідження В. Пасютинської “Жанрове багатоманіття українського радянського балету $(1917$ - 1975 р.)”.

Проблема становлення хореографічної освіти в Україні досліджена фрагментарно. Лише за останні десятиріччя 3'являються праці, що дотичні до аналізу розвитку хореографічної освіти в Україні. Це дисертаційні дослідження С. Забредовського "Педагогічні умови розвитку мотиваційної сфери студентів хореографічних спеціалізацій в процесі фахової підготовки у вузі культури”, О. Цвігун “Розвиток музичної освіти в навчальних закладах Києва (друга пол. XIX поч. ХХ ст.)" та ін.

Незаповненою прогалиною залишаються дослідження у царині історії педагогіки щодо засад хореографічної освіти початку XX ст. 


\section{СТАНОВЛЕННЯ УКРАЇНСЬКИХ ХОРЕОГРАФІЧНИХ ШКІЛ У КОНТЕКСТІ РОЗВИТКУ ЄВРОПЕЙСЬКОӤ ХУДОЖНЬОӤ КУЛЬТУРИ ПОЧАТКУ ХХ СТ.}

Можемо сміливо констатувати, що публікації та література 3 проблем історії хореографічної освіти в Україні є переважно навчальною i, загалом, не містить науково-теоретичного аналізу. В історії вітчизняної педагогіки, загалом, відсутнє цілісне, узагальнююче наукове дослідження хореографічної освіти, ії виникнення, становлення, еволюція тощо.

Виклад основного матеріалу. Бурхливий розвиток хореографічного мистецтва на початку ХХ століття у Європі обумовлений вагомими змінами, що були спричинені вимогами часу. Як зазначає Н. Горбатова - “естетика балетного спектаклю романтичної епохи вичерпала себе. Шаблонна конструкція та драматургія постановок, умовність відображення історичних і національних деталей, віртуозно досконала, але позбавлена змістовності традиційна виконавська манера були несумісні з вирішенням сучасних мистецьких завдань" [3, 240]. Відповідно, процес модернізації академічного балету став історично закономірним, відбулося переосмислення та оновлення танцювальних форм і традиційних виразових засобів.

На початку XX століття у “західноєвропейському балеті культивування рафінованих романтичних форм і самодостатньо-віртуозна техніка спричинила занепад класичного танцю в країнах 3 давніми i багатими хореографічними класичними традиціями (Італія, Англія, Франція), перетворення його на феєрію естрадносинтетичного плану, де власне балет посідав дуже скромне місце лише як одна із складових розважального видовища" [1].

Вимогам та зразкам традиційного балетного спектаклю були протиставлені нові принципи, які “драматизували танець, наповнюючи масові сцени ігровими моментами, спричиняли введення побутових деталей”. "У постановці на київській сцені балету А. Адана “Жізель” (1926) за петербурзькою редакцією Ж. Перро та М. Петіпа вишукана манера класичного танцю відрізнялася від суто канонічного стилю “Баядерки” i “Лебединого озера" стильовими особливостями, притаманними романтизму: драматичність, окриленість, почуттєвість тощо" [3].

Перша декада XX ст. особливо щодо розвитку різних жанрів інструментальної музики, що сприяло появі на українській сцені симфонічних класичних балетів, в “яких балетмейстери М. Дисковський, О. Горський, Л. Жуков, П. Вірський прагнули передавати високий поетичний і філософський зміст. Класичні балети М. Римського-Корсакова "Іспанське капричіо" (1925) (пост. М. Дисковський), П. Чайковського
“Лебедине озеро" (1927) (пост. П. Вірський та М. Болотов за хореографією М. Петіпа, вирізнялися вмілим поєднанням пантоміми та класичного танцю, чіткою композиційною структурою, виразною танцювальною мовою" [3, 242].

В умовах економічного занепаду, військової та політичної боротьби, спостерігалось виразне піднесення культурного і наукового життя, що було спричинено прагненням українського національного відродження. Лише за 1918 р. було засновано державну драматичну школу Український державний театр, урочисто відкрито Українську Академію Наук. У різних регіонах почали 3’являтися українські школи і гімназії.

Щодо розвитку театрального мистецтва “в Україні у 20-30-ті роки, у важких умовах громадянської війни, інтервенції, розрухи треба було зберегти балет, висунути нових керівників, почати виховання нових артистів. Ціною величезних зусиль це удалося зробити. Виникли школи, студії, інститути ритму, творчі майстерні і т.п." [4].

Розвиток мистецьких напрямків, течій і їх розгалужень зумовила поява яскравих режисерських індивідуальностей. "Несталість організаційних форм театру, інші чинники обумовили можливість творчої самореалізації кожного актора, давали змогу знайти врешті решт “свого” режисера, “свій” колектив, а отже і власне місце в складній системі української театральної культури" [4].

Загально прийнятою є думка, що мистецькі пошуки початку XX століття у їх різноманітності тяжіли до двох радикальних напрямів новаторству і традиціоналізму. Заміна старих форм, використання танцювальної техніки на балетній сцені, тимчасова відмова від пальцевої техніки - це був етап закономірний і необхідний.

Західна Європа довгий час, аж до середини XIX ст. включно, була центром розвитку класичного хореографічного мистецтва i спеціальної хореографічної професійної сценічної освіти.

Н. Горбатова, П. Білаш переконані, що українська національна школа хореографії і система класичної хореографічної професійної освіти почала формуватися теж ще у XIX ст. Визначальний вплив на їі розвиток мали західноєвропейська (французька, італійська, польська) та петербурзька хореографічні школа. "Перші балетні студії та школи класичного танцю були створені С. Ленчевським у 1894 р. при Київській опері, що працювала до 1909 р., Н. Тальоні-Дудинською в 1915 р. при Харківській опері, Р. Баланотті в 1916 р. при Одеському 


\section{СТАНОВЛЕННЯ УКРАЇНСЬКИХ ХОРЕОГРАФІЧНИХ ШКІЛ У КОНТЕКСТІ РОЗВИТКУ ЄВРОПЕЙСЬКОЇ ХУДОЖНЬОЇ КУЛЬТУРИ ПОЧАТКУ ХХ СТ.}

оперному театрі. В 1915 р. велику школу в Києві заснувала головний балетмейстер опери Б. Ніжинська, вихованка Петербурзького хореографічного училища і учениця М. Фокіна, яка розгорнула підготовку професійних артистів" [3]. 1919 роком в Україні датовано започаткування системи закладів підготовки фахівців балетмейстерів і танцюристів, засновану на класичній хореографії. Ця система продовжує існувати й успішно розвиватися і сьогодні.

Наприкінці XIX століття в Україні діяло 76 чоловічих і 43 жіночих гімназій під патронажем Міністерства народної освіти, 4 гімназії відомства Імператриці Марії, 5 інститутів шляхетних дівчат, а також численні приватні заклади, мистецькі програми, що відповідали гімназійним, саме в них викладали уроки класичного і бального танців.

У двадцятих роках XX століття відбулося заснування балетного театру України, це стало важливим надбанням національної музичнотеатральної культури. “Становлення класичного танцювального мистецтва причинило появу нових форм і пластичних забарвлень в українській хореографії, а саме урізноманітнилася лексика як народного, так і класичного танцю, почався процес зростання технічної майстерності виконавців та професіоналізму балетмейстерів" [4, 6].

“Розвиток української класичної балетної школи пов'язаний $з$ театром на Мерінгівській вулиці (нині ім. Заньковецької), де 17 серпня 1919 року оперою М. Лисенка “Утоплена" розпочала своє життя Державна українська музична драма, якій відомий російський балетмейстер і танцівник М. Мордкін та прима-балерина московського великого театру М. Фроман очолили першу українську балетну трупу і хореографічну студію при театрі” - відзначає дослідниця української хореографічної школи Н. Горбатова. Підготовку артистів балету за системою класичного танцю здійснювали у Києві Б. Ніжинська, у Центростудії балету, де вчився С. Лифар, з 1920 р., а також I. Чистякові балерина О. Гаврилова з Петербургу у 1918 р., К. Давидова, внучата племінниця П. Чайковського, з 1924 p.

Бурхливий розквіт української класичної хореографії йпрофесійної освіти розпочався у 1925 p. 3 відкриттям театрів опери та балету в Харкові 1925 р., Києві та Одесі 31926 р., а потім у Полтаві та у Вінниці.

Складний процес поєднання лексики класичного танцю і самобутніх форм українського хореографічного фольклору на основі структур традиційної балетної вистави “з канонічними паде-де, па-де-труа, варіаціями, кордебалетними ансамблями розпочався у заснованому в квітні
1931 року героїко-романтичному балеті "Пан Каньовський” М. Вериківського в інтерпретації визначного майстра класичної хореографії, відомого віртуозного танцівника і балетмейстера В. Литвиненка й досвідченого хореографафольклориста В. Верховинця" [2, 17].

Спроба перенесення на балетну сцену точних копій народних танців, записаних В. Верховинцем, виявились хибним шляхом. Вивчення історії першого українського національного балету доводить, що механічне поєднання класичних зразків і фольклорних форм не давало позитивних результатів. У майбутній балетній виставі на етапі репетицій виявилася суперечливість і неузгодженість двох різних інтонаційноконтрастних виражальних засобів: класичних зразків і автентичних танців українського хореографічного фольклору.

3 метою гармонійного поєднання у структурних формах національного балету та в лексиці класичного i народного танців, балетмейстери-постановники спробували театралізувати фольклорні зразки, ускладнивши ї віртуозними елементами класики. Ці пошуки виявилися ефективними: уперше в історії балетного театру класична та українська народносценічна хореографії об'єдналися, ставши плідним грунтом для створення своєрідної вітчизняної танцювальної школи.

Національний класичний балет “Лілея" К. Данькевича і балетмейстера Г. Березової, прем'єра якого відбулася в серпні 1940 року на сцені Київського оперного театру імені Т.Г. Шевченка, став не лише закономірним продовженням національних класичних музичнотеатральних традицій, а й якісно новим етапом у розвитку українського балетного театру.

Висновок. Становлення української школи хореографії та розвиток цього професійного мистецтва відбувалися у взаємодії трьох тенденцій - орієнтації на західноєвропейську (французьку та італійську) і російську хореографію, дотримання канонів класичного балету і класичної школи танцю, оновлення власних народних хореографічних традицій.

Загалом, розвиток української хореографії на початку ХХ ст. відбувався у контексті соціальних i історико-політичних зрушень в Україні. В цей період спостерігалося духовне піднесення, втілення культурних пошуків, поява могутніх талантів. Специфічною особливістю цього періоду розвитку української культури був її світоглядногуманістичний зміст, який спирався на загальнолюдські ідеали, відтворені в національних жанрових формах. 
Для становлення української професійної хореографічної освіти в Україні від перших студій і шкіл в XIX ст. велике значення мало оволодіння законами класики і ціннісними засадами західноєвропейської, зокрема французької та італійської хореографічних шкіл. Саме на початку $\mathrm{XX}$ ст. були закладені основи і започатковано систему навчальних хореографічних закладів, сформовану на традиціях класичного танцю, яка продовжує існувати і розвиватися сьогодні.

\section{ЛІТЕРАТУРА}

1. Білаш П.М. Імпресіонізм у європейському танцювальному мистецтві початку XX століття. Вісник Міжнародного слов'янського університету. Харків, 2003. T. VI. № 2. С.25-28.

2. Верховинець В. М. Теорія українського народного танцю. 5-е вид. Київ, 1990. 152 с.

3. Горбатова Н.О. Європейська хореографічна культура першої половини ХХ століття (історіографічний аспект). Наукові записки. Київ, 2003. Вип.54. С. 234-243.

4. Горбатова Н.О. Розвиток хореографічної освіти в Україні (кінець XIX - початок XX ст.). Питання культурологї: міжвідомчий збірник наукових статей. Випуск 17 / КНУКіМ. Київ, 2001. C. 6-12.
5. Загайкевич М. Українська балетна музика. Київ, 1969. 230 с.

\section{REFERENCES}

1. Bilash, P.M. (2003). Impresionizmu jevropejskomu tancjuvalnomu mystectvi pochatku XX stolittja [Impressionism in European dance art of the early twentieth century]. Herald of the International Slavic University, Kharkiv, vol. VI, no. 2, pp. 25-28. [in Ukrainian].

2. Verkhovynec, V.M. (1990). Teorija ukrajinskogho narodnogho tancju [Theory of Ukrainian folkdance]. Kyiv, 152 p. [in Ukrainian].

3. Ghorbatova, N.O. (2003). Jevropejska khoreoghrafichna kultura pershoji polovyn XX stolittja (istorioghrafichnyj aspekt) [European choreographic culture of the first half of the twenti eth century (historiographical aspect)]. Scientific notes, Kyiv, vol. 54, pp. 234-243. [in Ukrainian].

4. Ghorbatova, N.O. (2001). Rozvytok khoreoghrafichnoji osvityv Ukrajini (kinec XIX-pochatok XX st.)[Development of choreographic education inUkraine (end of the nineteenth and early twentieth centuries). Questions of cultural studies: interagency collection of scientific articles, vol. 17, pp.6-12. [in Ukrainian].

5. Zaghajkevych, M. (1969). Ukrajinska baletna muzyka [Ukrainian ballet music]. Kyiv, 230 p. [in Ukrainian].

Стаття надійшла до редакції 12.07.2019

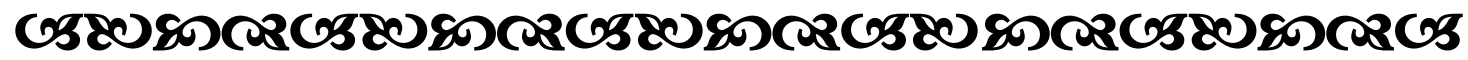

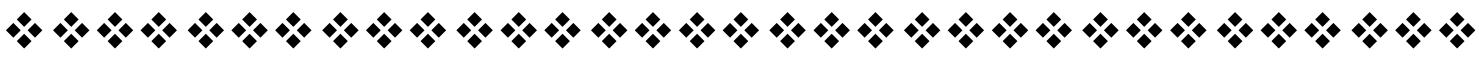 \\ “Dобрі слова залишають в душах людей преқрасний слід. Вони пом'яқшують, втішають $i$ зиіляють серие того, хто їх чує”.

$$
\begin{array}{r}
\text { Блез Ласқаль } \\
\text { франиузький фбілособ, письменник }
\end{array}
$$

"Теред людиною три шляхи до розуму: шлях мірқування - найшляхетніший; шлях наслідування - найлегший; шлях особистого досвіду - найважиий”.

\section{Конбууиій \\ давньокитайський білособ та політичний діяч}

"Навіть в суспільстві двох чоловік я неодмінно знайду, чому у них повчитися. Їх достоїнства я постараюся наслідувати, а на ӥхнедолікахсам буду вчитися".

$$
\begin{array}{r}
\text { Конфучій } \\
\text { давньокитайський філособ }
\end{array}
$$

“Мистеитво - вираження найглибших думокнайпростішим способом".

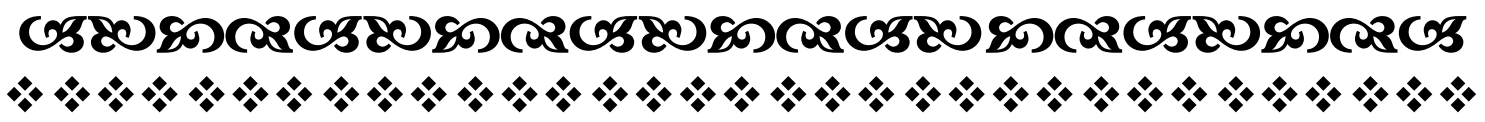

